\title{
INDEKS KESIAPAN PERGURUAN TINGGI DALAM MENGIMPLEMENTASIKAN SMART CAMPUS
}

\author{
Supratman $^{1}$, Sarjon Defit ${ }^{2}$, Vitriani $^{3}$ \\ ${ }^{1}$ Jurusan Pendidikan Teknik Informatika dan Komputer FTIK IAIN Bukittinggi Sumatera Barat \\ ${ }^{2}$ Fakultas Ilmu Komputer Uniersitas Putra Indonesia "YPTK" Padang Sumatera Barat \\ ${ }^{3}$ Jurusan Pendidikan Informatika FKIP Universitas Muhammadiyah Riau \\ Email: ${ }^{1}$ sefzaku@gmail.com, ${ }^{2}$ sarjonde@yahoo.co.uk, ${ }^{3}$ vitriani@umri.ac.id
}

(Naskah masuk: 06 Agustus 2018, diterima untuk diterbitkan: 06 Maret 2019)

\begin{abstract}
Abstrak
Keberhasilan perguruan tinggi memanfaatkan Teknologi Informasi dan Komunikasi (TIK) atau sering dikenal dengan istilah smart campus sebagai upaya kompetitif dan bernilai saing pada hakekatnya terletak pada sejumlah indikator seperti technoware, infoware, orgaware dan humanware. Upaya pencapaaian tujuan penggunaan smart campus tersebut dibutuhkan skema perencanaan yang matang dan need analysis yang menyeluruh. Banyak perguruan tinggi yang gagal mengimplementasikan smart campus disebabkan beberapa hal, seperti perencanaan yang tidak baik, tenaga ahli yang tidak siap, sarana prasarana yang kurang memadai, biaya awal pengembangan yang tidak tersedia dan kebijakan yang tidak konsisten. Penelitian ini bertujuan untuk melihat kesiapan perguruan tinggi dalam mengimplemetasikan smart campus sehingga dapat dijadikan acuan dalam pengembangan penggunaan TIK di kampus. Penelitian ini menggunakan jenis penelitian deskriptif kuantitatif yaitu penelitian yang mendeskripsikan suatu objek apa adanya dengan tahapan penelitian meliputi prasurvey, studi leteratur, penyebaran angket, analisis data dan temuan empiris. Data diperoleh dengan cara menggunakan angket penelitian. Hasil penelitian yang dilaksanakan di IAIN Bukittinggi memperlihatkan bahwa pengembangan cyber campus pada komponen ICT Use yang mencakup dimensi kebutuhan dan keselarasan serta dimensi proses dan tata kelola memasuki tahap kurang siap. Komponen ICT Readiness yang mencakup dimensi sumber daya teknologi pada kategori hampir berhasil. Komponen ICT Capability yang mencakup dimensi komunitas memasuki kategori belum berhasil. Komponen ICT impact sudah memasuki kategori hampir berhasil. Secara keseluruhan komponen pengembangan cyber campus dikategorikan hampir berhasil.
\end{abstract}

Kata kunci: smart campus, cyber campus, implementasi TIK, indeks TIK, ICT Blueprint

\section{READINESS INDEX OF HIGHER EDUCATION IN IMPLEMENTING SMART CAMPUS}

\begin{abstract}
The triumph of higher education in utilizing ICT or commonly termed as smart campus as a competitive strategy depends on some indicator like technoware, infoware, orgaware and human ware. To achieve such goal is not an easy task, it needs to have a good planning and a holistic needs analysis. Many educational institutions fail to implement smart campus due to some factors for instance bad planning, unready human resources, unsporting infrastructure, lack of fund and inconsistent policy. The research aims at revealing readiness index of higher education in utilizing ICT. The research uses descriptive quantitative approach research that describes an object as it is with research stages including presurvey, leterature studies, questionnaires, data analysis and empirical findings. Data were obtained by using a research questionnaire. The finding reveals that developing cyber campus in the component ICT Use which covers need, harmony, and process dimensions and governance is categorized less-ready. Component of ICT Readiness which covers dimension of technology resources is categorized as successful, meanwhile component of ICT capability of community dimension is not successful yet. Component of ICT impact comes to category near to successful. As a whole, the components of developing cyber campus are in the success category.
\end{abstract}

Keywords: smart campus, cyber campus, ICT Implementation, ICT index, readiness index 


\section{PENDAHULUAN}

Data yang rilis oleh Hotsuite We Are Social pada bulan Januari 2018 memperlihatkan bahwa jumlah penduduk Indonesia yang menggunakan internet sebanyak 132,7 juta pengguna atau sekitar $51 \%$ dari total penduduk Indonesia. Data ini menunjukkan akselarasi pertumbuhan pengguna internet di Indonesia yang signifikan. Pada tahun 2014 APJII merilis data pengguna internet di Indonesia sebesar 107 Juta pengguna dan mempredikasi pertumbuhan pengguna internet Indonesia sangat signifikan pada tahun-tahun mendatang.

Mencermati jumlah pengguna internet yang mengalami peningkatan secara signifikan, karena dengan aplikasi-aplikasi penerapan internet yang dalam tatanan luas diistilahkan dengan Teknologi Informasi dan Komunikasi (TIK) seseorang dapat dengan mudah melakukan kegiatan rutinitas secara realtime, tanpa dihalangi oleh tempat, waktu dan ruang. Artinya batasan geografis menjadi sirna karena keberadaan internet.(Choo, 2011)

Salah satu langkah untuk menunjang dan meningkatkan kualitas pelayanan di sebuah institusi adalah dengan pemanfaatan TIK. Tujuan utamanya adalah agar institusi mampu beradaptasi terhadap kemajuan yang ada, agar institusi tersebut dapat beroperasi secara efektif dan efisien. (Muftikhali \& Susanto, 2017). Dengan demikian penggunaan TIK dapat memberikan pengaruh yang baik bagi tercapainya visi dan misi serta tujuan institusi. (Bertho Molly, Andeka Rocky Tanaamah, 2017)

Perkembangan TIK mendorong berbagai intitusi pendidikan terutama Perguruan Tinggi untuk menggunakan internet dalam pengelolaan pendidikan sehingga dengan penggunaan internet Perguruan Tinggi dapat meningkatkan kualitas lulusan yang mampu bersaing baik di tingkat nasional maupun internasional. Saat ini perguruan tinggi dapat memanfaatkan TIK sebagai upaya untuk menghasilkan outcome yang berkualitas. Kondisi ini dikarenakan kelebihan peran strategis TIK di antaranya mampu mengatasi permasalahan kesenjangan kualitas sumber daya pendidikan dan model-model pembelajaran yang mulai tidak relevan. (Eko Indrajit; 2011;18-27).

Strategi-strategi yang digunakan dalam rangka mencapai tujuan pemanfaatan TIK cukup sulit. Dua komponen penting seperti perencanaan dan analisis kebutuhan haruslah matang dan menyeluruh. Banyak perguruan tinggi gagal memanfaatkan TIK. Beberapa penyebabnya adalah perencanaan yang mentah, SDM tidak siap, saranan prasarana yang kurang memadai, biaya tidak tersedia serta kebijakan pemanfaatan TIK yang tidak konsisten. Sementara salah satu tujuan penggunaan TIK di Perguruan Tinggi adalah keberbedaan dan pengurangan biaya operasional perguruan tinggi. (Jung \& Rha, 2000:37)

Perguruan tinggi dapat dikatakan berhasil dalam mengimplementasikan TIK dilihat dari sejumlah indikator yaitu tecnoware, infoware, orgaware dan human ware. (Eko Indrajit; 2011;87). Tecnoware meliputi teknologi yang akan dipakai. Infoware meliputi informasi yang diperoleh serta orgaware meliputi pengelolaan penerapan TIK dan humanware meliputi pengelola aplikasi TIK di PT. semua indikator tersebut berdampak pada keluwesan, dan kualitas sehingga PT dapat memanfaatkan TIK secara efektif.

Pelaksanaan implementasi penggunaan TIK hendaknya sesuai dengan kajian keilmuan dan sejalan dengan perkembangan teknologi. Pelaksanaan pengembangan sains dan teknologi harus adanya jembatan yang dapat menghubungkan keduanya agar tidak terjadi ketimpangan yang berakhir pada kemudharatan dan tidak tercapainya tujuan akhir. Pengembangan teknologi meliputi peningkatan kualitas, peningkatan penyediaan masukan (input) pelengkap serta peningkatan mutu tata laksana. Input (masukan) dan tata laksana melibatkan unsur manusia dan benda. Kadangkala pencarian masukan (input) serta pelaksnaan tata laksana tidak mengindahkan sisi kemanusiaan sehingga prinsip awal dari pengembangan teknologi tidak lagi menjadi landasan berpijak. (Saefuddin; 2010 : 264)

Pemanfaatan TIK secara efektif dan berkelanjutan dapat terwujud jika TIK telah menjiwai dan mewarnai kinerja semua komponen perguruan tinggi. TIK dapat menjadi isu strategis apabila TIK dapat mempengaruhi sikap dan kinerja komponen di PT secara komprehensif, dan tidak lagi pencapaian keberhasilan yang semu dan kolosal yang dapat hilang sesaat.

Tulisan ini bertujuan untuk mengidentifikasi indeks kesiapan perguruan tinggi dalam mengimplementasikan smart campus atau penggunaan TIK dalam pengelolaan perguruan tinggi. Sehingga dengan mengetahui indeks kesiapan implementasi smart campus, perguruan tinggi dapat menjadikan informasi tersebut sebagai ${ }^{\text {barometer }}$ dalam pengembangan TIK di perguruan tinggi.

\section{TINJAUAN PUSTAKA}

Sejumlah perguruan tinggi yang telah memanfaatkan TIK dalam mengelola PT memakai ragam istilah, seperti Sistem Informasi Kampus Sistem Informasi Akademik (SIA), e-learning, dan ada yang memakai istilah smart university atau smart campus. Istilah-istilah tersebut belum ada standarisasi atau indikator yang disepakati untuk dimanfaatkan dalam membangun sebuah sistem pemanfaatan TIK di pergurun tinggi. Ketiadaan standarisasi tersebut disebabkan karena perbedaan analisis dan kebutuhan dari setiap perguruan tinggi. Sementara di Amerika Sekirat telah disepakati sebuah standar untuk pembangunan infrastruktur jaringan yang disebut dengan The Open Science Grid (OSG). OSG merupakan sebuah standar ilmiah dalam membangun infrastruktur jaringan. Standar tersebut digunakan di berbagai bidang salah satunya adalah Pendidikan di 
Perguruan Tinggi. (Weitzel, Bockelman, Fraser, \& Pordes, 2010)

Banyak universitas telah mengembangkan ragam teknologi informasi dalam rangka mendukung kegiatan akademik, sosial dan administratif. (Han \& Han, 2014). Hal ini tidak terlepas dari keungglan teknologi tersebut yang mampu mengatasi permasalahan keterbatasan waktu, tempat dan ruang. Hakekat dari cyber campus adalah adanya kolaborasi yang kuat antara sistem fisik dan non fisik. (Lee, 2015).

Penelitian relevan yang terkait dengan pembahasan ini adalah penelitian yang dilakukan oleh Qilbaaini Effendi Muftikhali dan Tony Dwi Susanto yang membahas tentang pengembangan $e$ government. Tujuan penelitian tersebut adalah melihat model pengembangan e-government serta melihat kelebihan dan kekurangannya. Salah satu hasil penelitian tersebut menyatakan bahwa dalam pengembangan e-government terdapat beberapa model dan kategori di mana setiap kategori memiliki tujuan pengukuran, cara dan sudut pandang pengembangan yang berbeda. (Muftikhali \& Susanto, 2017).

Penelitian relevan yang kedua adalah penelitian yang dilakukan oleh Bertho Molly, Andeka Rocky Tanaamah dan Melkior Nikolar Ngalumsine Sitokdana yang berjudul Analisis Kinerja Sistem Informasi dan Teknologi Informasi untuk Menunjang Kinerja Karyawan Menggunakan Framework IT Balanced Scorecard: Studi Kasus Pada Wi-Fi Universitas Kristen Satya Wacana. Penelitian ini bertujuan untuk mengukur bagaimana tingkat pemanfaatan TIK berdasarkan kinerja karyawan. Hasil penelitian memperlihatkan bahwa masih dibutuhkannya penambahan Sumber Daya Manusia (SDM) untuk membantu kinerja karyawan baik dalam hal penanganan komplain maupun penyelesaian proyek mengingat aplikasi TIK dibutuhkan dan digunakan oleh semua civitas serta perlu adanya evaluasi dan upgrade sistem aplikasi monitoring. (Bertho Molly, Andeka Rocky Tanaamah, 2017)

Berdasarkan kedua penelitian di atas maka diambil kesimpulan bahwa untuk mengembangkan TIK di sebuah institusi dalam hal ini perguruan tinggi dibutuhkan model pengembangan serta kategorikotegori yang berbeda mengingat setiap kategori memiliki karakteristik dan cara pengukuran yang berbeda. SDM sangat dibutuhan dalam pengembangan TIK di sebuah instritusi. Terutama digunakan untuk monitoring aplikasi-aplikasi implementasi TIK di perguruan tinggi.

\section{METODE PENELITIAN}

Jenis penelitian yang dipakai ialah deskriptif kuantitatif atau disebutkan juga pendekaan survey (Sugiyono; 2013:12) dimana peneliti menanyakan ke beberapa responden (sample) tentang keyakinan, pendapat, karakteristik suatu objek dan kejadian yang berlalu atau saat ini. Penelitian ini dilakukan untuk mengambil suatu generalisasi dari sebuah penelitian. Penelitian deskriptif kuantitatif mengumpulkan data dengan cara menggunakan instrumen penelitian berupa angket dan analisis data bersifat deskriptif kuantitatif.

\subsection{Tahapan Penelitian}

Adapun tahapan dalam penelitian ini dapat digambarkan sebagai berikut.

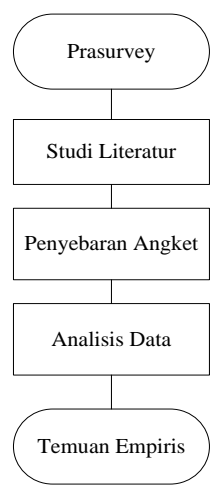

Gambar 1. Tahapan Penelitian

Adapun pada setiap tahapan terdapat kegiatankegiatan sebegai berikut:

1. Prasuervey

Prasurvey dilakukan dalam rangka untuk melihat kondisi yang ada saat ini (cuurent system) beserta masalahmasalah yang terkait dengan pengembangan cyber campus.

2. Studi Literatur

Dilaksanakan untuk mencari teori dan konsep yang berhubungan dengan penelitian dengan cara menelaah jurnal-jurnal ataupun buku-buku yang berhubungan dengan objek dan permasalahan penelitian.

3. Penyebaran Angket

Angket yang digunakan adalah model angket dalam program ICT Pura. Angket disusun berdasarkan 4 (empat) komponen yaitu ICT Use, ICT Readiness, ICT Capability, dan ICT Impact. Setelah angket disusun lalu disebarkan ke sampel yang telah dipilih yaitu sebanyak 265 sampel.

4. Analisis Data

Angket yang telah diisi dan dikembalikan oleh sampel, dianalisis menggunakan formula pengukuran indeks dengan 3 (tiga) domaian yaitu pemetaan entitas, penghitungan indeks serta pemberian peringkat. Pemberian peringkat dimaksudkan pemberian posisi atau pada kategori mana kesiapan sebuah perguruan tinggi dalam implementasi TIK. 


\section{Temuan Empiris}

Berdasarkan analisis data, maka dapat diinterpretasikan hasil dari pengolahan data. Dalam tahap ini akan diperoleh posisi kesiapan pergurun tinggi dalam iimplementasi TIK atau cyber campus.

\subsection{Populasi dan Sampel}

Penelian ini dilaksanakan di IAIN Bukittinggi dengan populasi adalah seluruh civitas akademik IAIN Bukittinggi yang terdiri dari Pimpinan, Dosen, Mahasiswa dan Karyawan. Jumlah populasi dapat dilihat dalam tabel 1 . berikut :

\begin{tabular}{llr}
\multicolumn{3}{c}{ Tabel 1. Populasi Penelitian } \\
\hline No & \multicolumn{1}{c}{ Jenis Populasi } & Jumlah \\
& & 24 \\
1 & Pimpinan (Rektor \&Warek) & 109 \\
3 & Dosen & 5340 \\
4 & Mahasiswa & 49 \\
\hline \multicolumn{3}{c}{ Karyawan } \\
\hline \multicolumn{2}{c}{ Total } \\
\hline \multicolumn{3}{c}{ Sumber : EMIS IAIN Bukittinggi 2014 }
\end{tabular}

Banyaknya anggota sampel didasari teknik sampling yang dipakai. Beberapa teknik sampling dan jumlah sampel dalam penelitian ini terlihat dalam tabel. 2 berikut ini.

\begin{tabular}{cccc}
\multicolumn{4}{c}{ Tabel 2. Sampel Penelitian } \\
\hline No & $\begin{array}{c}\text { Jenis } \\
\text { Populasi }\end{array}$ & Teknik Sampling & $\begin{array}{c}\text { Jml } \\
\text { Sampel }\end{array}$ \\
\hline 1 & Pimpinan & $\begin{array}{l}\text { Purposive random } \\
\text { sampling } \\
\text { Simple random }\end{array}$ & 24 \\
2 & Dosen & $\begin{array}{l}\text { sampling } \\
\text { Stratified Random } \\
\text { sampling } \\
\text { Simple Random } \\
\text { Sampling }\end{array}$ & 25 \\
4 & Mahasiswa & 16 \\
\hline \multicolumn{5}{c}{ Karyawan } & 260 \\
\hline
\end{tabular}

Purposive random sampling digunakan dengan pertimbangan bahwa yang akan dijadikan sampel adalah semua populasi yang ada, yaitu pimpinan PT. Simple random sampling dipakai dikarena populasi diasumsikan tidak memiliki tingkatan atau strata, sementara penggunaan teknik stratified random sampling karena mahasiswa yang aktif terdiri dari tingkatan-tingkatan yaitu semester 2, 4, 6 dan 8 . Masing-masing tingkatan diambil secara acak sebanyak 50 sampel.

\subsection{Instrument Penelitian}

Instrumen yang dipakai untuk penelitian ini mengacu pada model instrument yang digunakan dalam program ICT Pura. Instrument yang disusun berdasarkan 4 (empat) komponen yaitu ICT Use, ICT Readiness, ICT Capability, dan ICT Impact serta 5 (lima) dimensi yaitu; dimensi kebutuhan dan keselarasan, dimensi proses dan tata kelola, dimensi sumber daya teknologi, dimensi komunitas serta dimensi keluaran dan manfaat. (Indrajit, 2011). Untuk mengakomodir semua komponen dan dimensi di atas maka disusun instrument sebanyak 150 butir instrumen.

Instrument yang digunakan adalah instrument nontest yaitu angket. Angket disusun menggunakan skala model likert menggunakan 6 (enam) pilihan jawaban berbobot $0-5$. Instrumen penelitian ini tidak menggunakan pengukuran yang positif dan negatif tetapi menggunakan konsep pengkuran proportional artinya bobot yang diberikan berdasarkan besar kecilnya nilai aspek yang diukur di lapangan.(Supratman, 2014)

Jumlah instrumen yang digunakan dalam penelitian ini sebanyak 150 instrumen yang mencakup 4 (empat) komponen, 5 (lima) dimensi pengembangan dengan 13 sub dimensi. (Supratman, 2014:661). Distribusi instrument dapat dilihat dalam table 3 berikut :

Tabel 3. Jumlah Instrument dan Pendistribusiannya

\begin{tabular}{|c|c|c|c|}
\hline Komp. & Dimensi & Sub Dimensi & $\mathrm{Jml}$ \\
\hline \multirow{11}{*}{ ICT Use } & Kebutuhan dan & & 8 \\
\hline & Keselarasan & & \\
\hline & & a. Perencanaan dan & 12 \\
\hline & & Pengorganisasian & \\
\hline & Proses dan Tata & b. Pengadaan dan & 5 \\
\hline & Kelola & pembangunan & \\
\hline & Penyelenggaraan & $\begin{array}{l}\text { c. Penerapan dan } \\
\text { pengelolaan }\end{array}$ & 6 \\
\hline & & $\begin{array}{l}\text { d. Pengawasan dan } \\
\text { pengembangan }\end{array}$ & 6 \\
\hline & & a. Pimpinan & \\
\hline & Komunitas & b. Dosen & 12 \\
\hline & & c. Mahasiswa & \\
\hline \multirow{9}{*}{$\begin{array}{l}\text { ICT } \\
\text { Readiness }\end{array}$} & \multirow{8}{*}{$\begin{array}{l}\text { Sumber Daya } \\
\text { Teknologi }\end{array}$} & $\begin{array}{l}\text { a. Karyawan } \\
\text { a. Jaringan }\end{array}$ & 6 \\
\hline & & Infrastruktur & \\
\hline & & b. Piranti Keras dan & 6 \\
\hline & & Kanal Akses & \\
\hline & & c. Piranti Lunak & 7 \\
\hline & & Aplikasi dan & \\
\hline & & Program & \\
\hline & & d. Data, Informasi dan & 6 \\
\hline & \multirow{4}{*}{ Komunitas } & a. Pimpinan & 16 \\
\hline \multirow{3}{*}{$\begin{array}{l}\text { ICT } \\
\text { Capability }\end{array}$} & & b. Dosen & 9 \\
\hline & & c. Mahasiswa & 9 \\
\hline & & d. Karyawan & 9 \\
\hline ICT & Keluaran dan & & 19 \\
\hline \multirow[t]{2}{*}{ Imapct } & Manfaat & & \\
\hline & \multicolumn{2}{|c|}{ Jumlah Instrumen } & 150 \\
\hline
\end{tabular}

Instrumen yang valid dan reliabel merupakan indicator utama dalam menghasilkan penelitian yang valid dan reliable. Instrumen yang valid harus memiliki validitas internal dan validitas ekternal. Instrumen yang memiliki validitas internal adalah instrument yang yang memiliki kriteria yang secara teoritis telah mencerminkan apa yang hendak dikukur. Sementara instrument yang memiliki validitas ekternal adalah instrument yang disusun merujuk kepafa fakta yang ditemukan. (Sugiyono : 2013;169). Validitas instrument penelitain merupakan sejauh mana instrument penelitain 
mampu menangkap makna secara actual apa yang hendak diukur (Lee Abbot \& McKenney, 2013:81).

Instrument penelitian yang hendak diukur adalah validitas Internal dan validitas ekternal instrument. Validitas internal instrumen berupa construct validity (validitas konstruk) yang disusun berdasarkan fakta-fakta empiris dengan indikator bahwa alat ukur dapat dipakai untuk mengukur variabel yang telah didefinisikan sebelumnya. Adapun cara mengukur validitas internal instrument yang berupa validitas konstruk yaitu dengan berkonsultasi dengan ahli. Pengujuan validitas eksternal dengan cara melakukan perbandingan antara indicator-indikator yang terdapat dalam instrument dengan fakta di lapangan. Jika tidak ada perbedaan antara kriteria dengan fakta di lapangan, maka dapat dinyatakan bahwa instrument telah memiliki validitas ekternal.

\subsection{Teknik Analisis Data}

Paradigma ICT Pura dijadikan acuan untuk analisis penggunaan TIK di Perguruan Tinggi. Terdapat 3 (tiga) domain atau ranah pengukuran, yaitu : ranah pemetaan entitas, ranah penghitungan indek dan ranah pemberian peringkat. Tiga ranah penggunaan TIK terlihat dalam gambar 1 berikut ini.

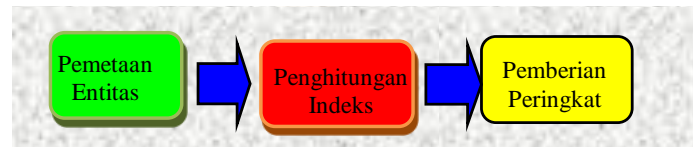

Gambar 2. Domain Implementasi TIK

Fokus utama dari domain pemetaan entitas adalah situasi dan kondisi ekosistem yang mencakup 5 (lima) dimensi yaitu: Pertama; dimensi kebutuhan dan keselarasan yang terkait dengan kebutuhan dan harapan dari semua komponen atau stake holder di Perguruan Tinggi. Kedua; dimensi proses dan tata kelola penyelenggaraan dan terdiri dari 4 (empat) kegiatan, yaitu : planning dan organizing, development dan procurement, implementation dan management serta conrtoling. Ketiga; dimensi infrastruktur yang terdiri network, hardware, software, database dan information serta human resources. Keempat; Dimensi komunitas yaitu Pimpinan PT; Dosen; Mahasiswa; staf unit TIPD (Teknologi Informasi dan Pangkalan Data). Kelima; dimensi output dan outcome yang merupakan hasil system yang akan dirasakan oleh seluruh komponen di PT. Kelima dimensi terlihat dalam gambar. 2 .

Tujuan dari penghitungan indeks adalah untuk mengetahui kesiapan PT dalam mengimplementasi smart Campus (CYCA). Penghitungan indeks dilakukan setelah kegiatan pemetaan entitas selesai.

Tujuan dari penghitungan indeks adalah untuk mengetahui kesiapan PT dalam mengimplementasi smart Campus (CYCA). Penghitungan indeks dilakukan setelah kegiatan pemetaan entitas selesai.

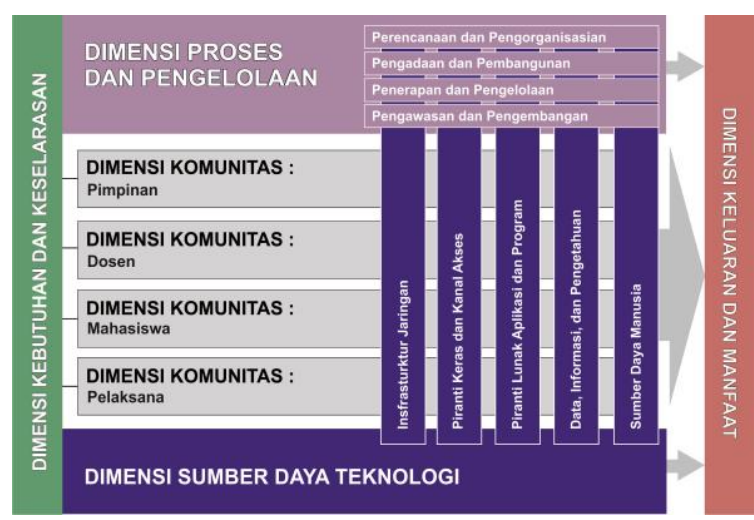

Gambar 3. Dimensi Domain Pemetaan Entitas

Penghitungan indeks melibatkan 4 (empat) komponen yang akan diukur yaitu komponen penggunaan (ICT Use), komponen kesiapan (ICT Readiness), komponen kemampuan (ICT Capability) serta komponen dampak (ICT Impact) dari implementasi TIK. Adapun pembobotan dalam penghitunagn indeks ini $40 \%$ untuk ICT Use, hal ini mengingat seluruh kegiatan berlandaskan dengan kebijakan, peraturan, dan keputusan pimpinan PT. Komponen ICT Readiness diberi bobot $20 \%$. Pertimbangannya adalah ketersediaan infrastruktur merupakan pondasi dasar untuk implementasi TIK di PT. Kompoen ICT Capabilitydiberi bobot sebesar 25\%. Pertimbanganya adalah PT akan berkembang jika memiliki sumber daya dan kemampuan yang cukup. Komponen ICT Impact diberi bobot $10 \%$ dengan pertimbangan bahwa civitas akademik akan memperoleh manfaat langsung dari keberadaan TIK, Nilai pemboboton untuk setiap komponen, dimensi dan sub dimensi di atas dapat dilihat dalam tabel 4 berikut :

\begin{tabular}{|c|c|c|}
\hline Dimensi & Sub Dimensi & $\%$ \\
\hline Kebutuhan dan & & 100 \\
\hline Keselarasan & a. Planning and Organizing & 25 \\
\hline Proses dan Tata & $\begin{array}{l}\text { b. Developmnent dan } \\
\text { Procurement }\end{array}$ & 25 \\
\hline $\begin{array}{l}\text { Kelola } \\
\text { Penyelenggaraan }\end{array}$ & $\begin{array}{l}\text { c. Implementation dan } \\
\text { Management }\end{array}$ & 25 \\
\hline & d. Controling & 25 \\
\hline & e. Network & 30 \\
\hline Sumber Daya & $\begin{array}{l}\text { f. Hardware and Access } \\
\text { Channel }\end{array}$ & 20 \\
\hline Teknologi & $\begin{array}{l}\text { g. Softwrae and Program } \\
\text { h. Data, Information and } \\
\text { Knowledge }\end{array}$ & $\begin{array}{l}20 \\
20\end{array}$ \\
\hline & e. Rector & 40 \\
\hline Komunitas & $\begin{array}{l}\text { f. Lecturer } \\
\text { g. Student } \\
\text { h. Employees }\end{array}$ & $\begin{array}{l}20 \\
30 \\
10\end{array}$ \\
\hline $\begin{array}{l}\text { Keluaran dan } \\
\text { Manfaat }\end{array}$ & & 100 \\
\hline
\end{tabular}

Berdasarkan nilai bobot yang telah ditetapkan maka dapat diperoleh indeks implemetasi TIK atau smart campus dengan menggunakan formula sebagai berikut :

Indeks $=\mathrm{NR}_{\mathrm{IU}} * 40 \%+\mathrm{NR}_{\mathrm{IR}} * 20 \%+\mathrm{NR}_{\mathrm{IC}} * 25 \%+\mathrm{NR}_{\mathrm{II}} * 15 \%$ 
$\mathrm{NR}_{\mathrm{IU}}=$ Rerata untuk ICT Use

$\mathrm{NR}_{\mathrm{IR}}=$ Rerata untuk ICT Readiness

$\mathrm{NR}_{\mathrm{IC}}=$ Rerata untuk ICT Capability

$\mathrm{NR}_{\mathrm{II}}=$ Rerata untuk ICT Impact

Pemberian peringkat berdasarkan nilai besaran indeks implementasi smart campus didapatkan berdasarkan formua di atas. Penggunaan model skala likert digunakan dalam sistem scoring yaitu antara 0 sampai 5 dengan kebermaknaan sebagai berikut :

$0=$ Implementasi Smart Campus gagal / tidak siap

$1=$ Implementasi Smart Campus kurang siap

$2=$ Implementasi Smart Campus hampir siap

$3=$ Implementasi Smart Campus telah siap / berhasil

$4=$ Implementasi Smart Campus telah siap dan mampu bersaing

5 = Implementasi Smart Campus sangat berhasil

Dengan peringkat tersebut maka perguruan tinggi akan dapat melihat posisi implementasi Smart Campus.

\section{TEMUAN EMPIRIS}

Data hasil penelitian dipaparkan berdasarkan struktur atau varibel penelitian yang diteliti, yaitu dimensi dan komponen.

\subsection{Dimensi pengembangan smart campus}

Berdasarkan data yang dikumpulkan bahwa didapatkan skor untuk dimensi pemenuhan dan keselarasan sebesar 2.857, dimensi proses dan tata kelola penyelenggaraan sebesar 1.575, dimensi ketersediaan sumber daya teknologi sebesar 2.807, dimensi komunitas sebesar 1.914 dan skor untuk dimensi keluran dan manfaat sebesar 2.900. Distribusi skor dari jawaban sampel dapat dilihat dari tabel 5 dan gambar 3 di bawah ini.

Tabel 5. Nilai dimensi Implementasi Smart Campus

\begin{tabular}{ll}
\hline \multicolumn{1}{c}{ Dimensi } & Nilai \\
\hline Pemenuhan Kebutuhan dan Keselarasan & 2.857 \\
Proses dan Tata Kelola Penyelenggaraan & 1.575 \\
Ketersediaan Sumber Daya & 2.807 \\
Dukungan Stakeholder & 1.914 \\
Keluaran dan Manfaat & 2.900 \\
\hline
\end{tabular}

a. Data dimensi kebutuhan dan keselarasan

Terdapat 8 (delapan) instrument yang terkait pada dimensi kebutuhan dan keselarasan. Data hasil penelitian yang telah diuangkapkan di atas dapat diinterpretasikan skor yang diperoleh sebesar 2.875 berarti bahwa dalam pengembangan smart campus dimensi ini hampir siap dan telah siap karena skor yang diperoleh berada pada range 2-3 seperti range yang telah ditetapkan sebelumnya. Dari data tersebut dapat disimpulkan bahwa dimensi kebutuhan dan keselarasan telah memenuhi persyaratan kesiapan dalam rangka mengembagan smart campus di IAIN Bukittinggi

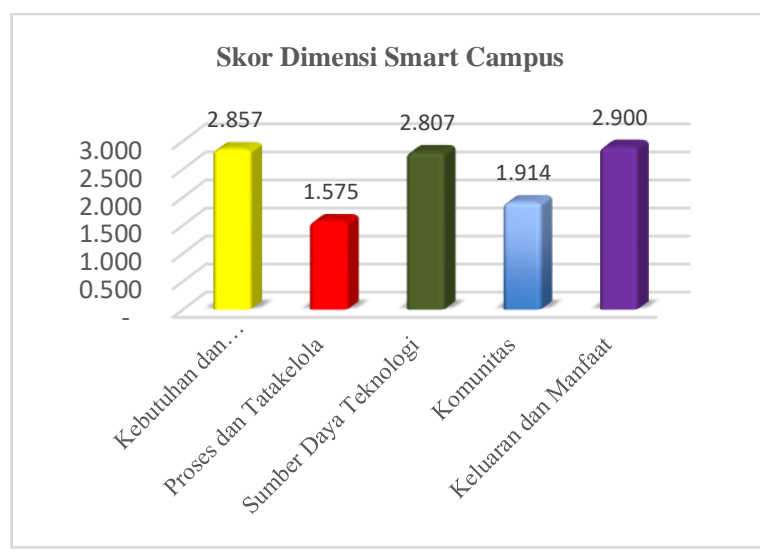

Gambar 4. Distribusi skor Dimensi Implementasi Smart Campus

b. Data dimensi proses dan tatakelola

Berdasarkan instrument didapat data untuk dimensi proses dan tatakelola seebsar 1.575. Pada dimensi ini terdapat 4 (empat) sub dimensi yaitu perencanaan dan pengelolaan diperoleh skor sebesar 1.900, sub dimensi pengadaan dan pembangunan sebesar 2.400, sub dimensi penerapan dan pengelolaan diperoleh skor sebesar 1.400 dan sub dimensi pengawasan dan pengembangan sebesar 0.600. Adapun distribusi skor untuk sub dimensi ini dapat dilihat pada gambar 4 di bawah ini.

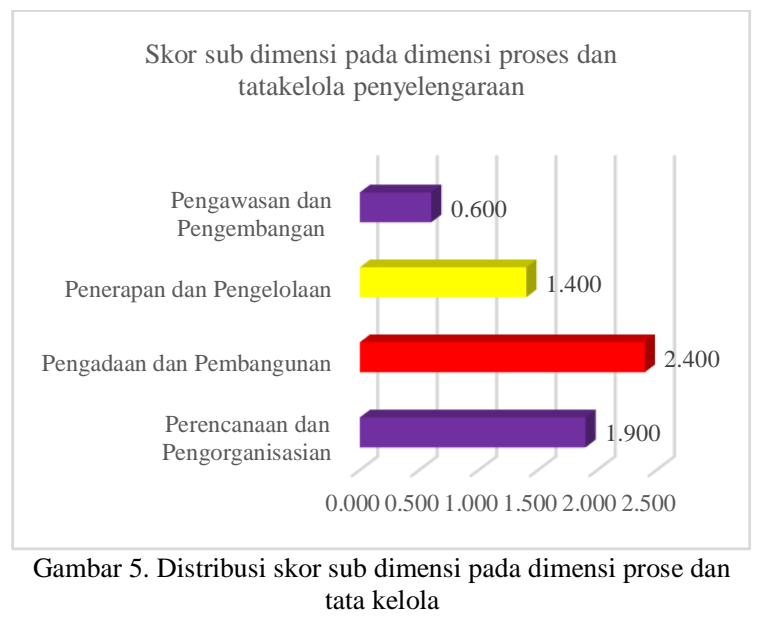

Pada sub dimensi perencanaan dan pengorganisasian skor yang diperoleh sebesar 1.900 artinya pada sub dimensi ini masih kurang siap dalam menyongsong smart campus akan tetapi sudah mendekati hamper siap. Sementara pada sub dimensi pengadaan dan pembangunan, skor yang diperoleh sebesar 2.400, artinya pada sub dimensi ini telah hampir siap dalam rangka mengembangkan smart campus. Pada sub dimensi penerapan dan pengelolaan diperoleh skor sebesar 1.400, sub dimensi dikategorikan belum siap untuk pengembangan smart campus. Sementara sub dimensi pengawasan dan pengembangan didapat skor 
sebesar 0.600, dimensi ini diklasifikasikan dengan subdimensi yang sangat tidak siap. Berdasarkan keempat sub dimensi dalam dimensi ini diperoleh skor sebesar 1.575, dengan skor tersebut menunjukkan bahwa dimensi proses dan tatakelola ini dikategorikan belum siap.

c. Data dimensi sumber daya teknologi

Skor yang didapatkan dari sampel untuk dimensi sumber daya teknolgi sebesar 2.807 dan pada dimensi ini terdapat 4 (empat) sub dimensi yaitu sub dimensi insfrastrktur jaringan yang memperoleh skor 2.833, sub dimensi hardware dank anal akses dengan skor sebesar 3.667, sub dimensi data, informasi dan pengetahuan dengan skor 2.333 serta kompetensi individu dengan skor 2.524. Adapun distribusi skor pada dimensi ini dapat dilihat pada gambar 5 di bawah ini.

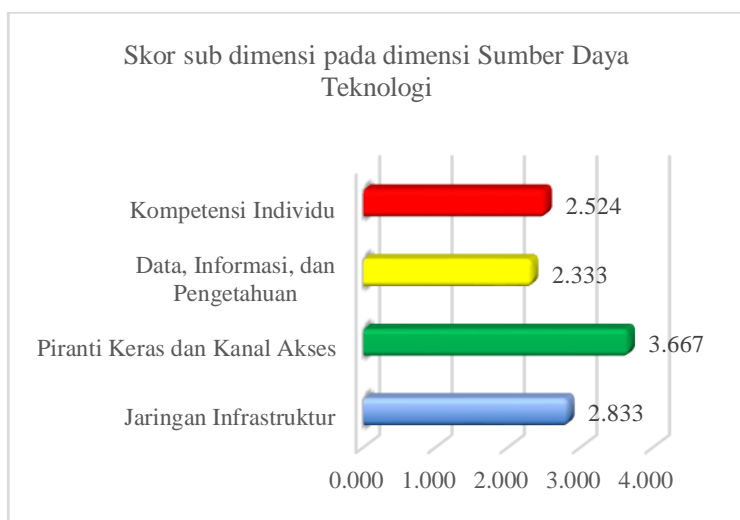

Gambar 6. Distribusi skor sub dimensi pada dimensi sumber daya teknologi

Subdimensi infrastruktr jaringan yang memperoleh skor sebesar 2.833 yang berarti sub dimensi ini sudah mendekati telah siap dalam pengembangan smart campus. Sementara sub dimensi hardware dan kanal akses yang memperoleh skor sebesar 3.667, dengan skor tersebut sub dimensi ini kategorikan dengan telah siap dan mendekati mampu untuk bersaing. Sub dimensi data, informasi dan pengetahuan dengan skor 2.333 dikategorikan hampir siap. Dan sub dimensi kompetensi individu dengan skor 2.524 dengan artian bahwa sub dimensi ini dikategorikan hampir siap untuk smart campus. Secara keseluruhan untuk dimensi sumber daya teknolgi dengan skor yang diperoleh sebesar 2.807 dikategorikan hampir siap dalam pengembangan smart campus.

\section{d. Data dimensi Komunitas}

Skor yang diperoleh untuk dimensi komunitas sebesar 1.914. Pada dimensi ini terdapat 4 (empat) sub dimensi yaitu sub dimensi pimpinan dengan skor sebesar 1.429, sub dimensi dosen dengan skor sebesar 2.143, sub dimensi mahasisswa dengan skor 2.000 dan sub dimensi pengelola dengan skor sebesar 3.00. Distribusi skor untuk dimensi komunitas dapat dilihat dalam gambar 6. di bawah ini

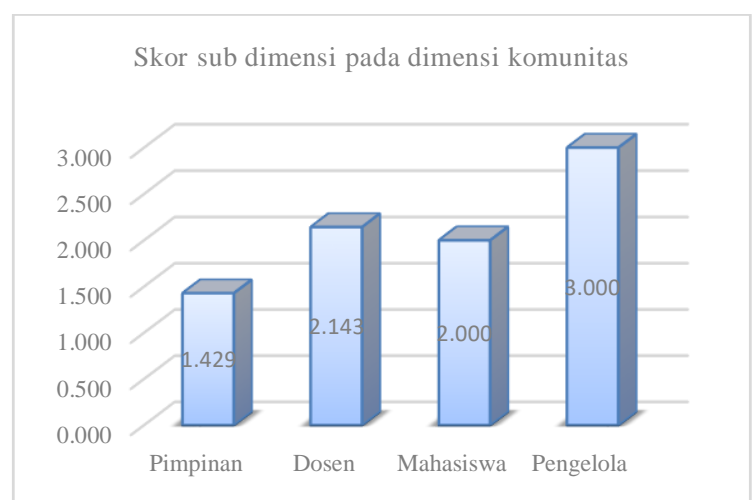

Gambar 7. Distribusi skor sub dimensi pada dimensi komunitas

Sub dimensi pimpinan dengan skor 1.429 , artinya pimpinan belum memberikan kontribusi yang berupa kebijakan dalam mendukung pengembangan smart campus hal ini terlihat skor yang diperoleh yang dikategorikan pada skala belum siap atau kurang siap. Sub dimensi dosen dengan skor yang diperoleh sebesar 2.144 juteru hampir siap dalam menghadapi pengembangan smart campus hal ini terbukti dengan skala skor yang diperoleh yaitu berada pada skala hamper siap. Sementara sub dimensi mahasiswa dengan skor yang diperoleh sebesar 2.000 juga mengindikasikan bahwa sub dimensi ini hampir siap dalam mengembangakan smart campus. Sub dimensi terakhir dalam dimensi ini adalah pengelola yang memeroleh skor 3.000, data ini menunjukkan bahwa pengelola sudah memasuki fase siap untuk pengembangan smart campus.

e. Data dimensi keluaran dan manfaat

Data yang diperoleh untuk dimensi keluaran dan manfaat adalah seebsar 2.900. Data ini memperlihatkan bahwa dimensi ini sudah memasuki fase hampir siap dalam pengembangan smart campus.

\subsection{Komponen pengembangan smart campus}

Kelima dimensi di atas merupakan sub komponen dari 4 (empat) komponen pengembangan model smart campus yaitu ICT Use, ICT Readiness, ICT Capability dan ICT Impact. Skor yang diperoleh untuk komponen ICT Use sebesar 1.446, komponen ICT Readiness diperoleh 2.739, komponen ICT Capability dengan skor 1.852 serta komponen ICT Impact dengan skor 2.9.00. Distribusi skor untuk keempat komponen dapat dilihat dalam tabel 6 dan gambar 7 di bawah ini.

\begin{tabular}{cc} 
Tabel 6. Nilai komponen pengembangan smart campus \\
\hline Komponen & Nilai \\
\hline ICT Use & 1.446 \\
ICT Readiness & 2.739 \\
ICT Capability & 1.852 \\
ICT Impact & 2.900 \\
\hline
\end{tabular}




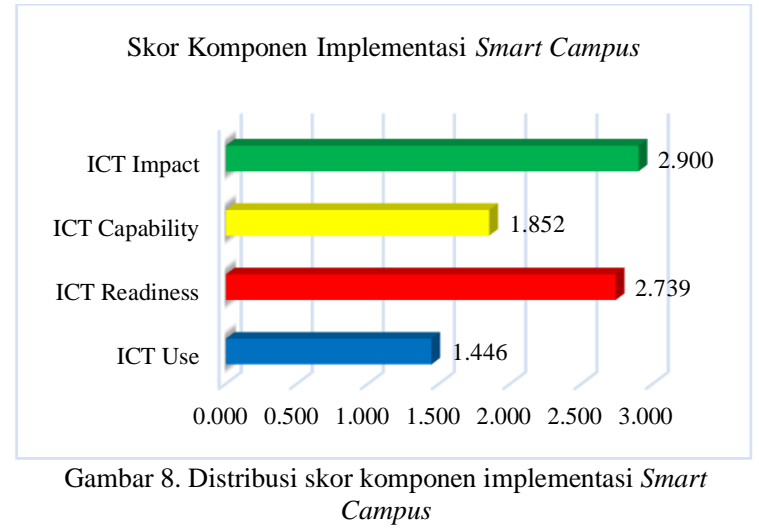

1. Komponen ICT Use

Komponen ini terdiri dari dimensi kebutuhan dan keselarasan serta dimensi proses dan tatakelola. Komponen ini mencakup hal-hal yang berkaitan dengan analisis kebutuhan serta identifikasi kebutuhan terhadap aspek-aspek pengembangan smart campus serta hal-hal yang berkaitan dengan kebutuhan dan keinginan dari berbagai komponen di PT terhadap keberadaan ICT dalam beragam kontek aktifitas di Perguruan Tinggi. Komponen ini sangat erat hubungannya dengan kebijakan yang akan diambil oleh pemangku kepentingan salah satunya adalah pimpinan perguruan tinggi. Beberapa kebijakan tersebut diantaranya bagaimana perencanaan dan pengorganisasian smart campus, pengadaan insfrastrukur serta pembangunan dan pengembangannya dan pengawasan terhadap kegiatan pengembangan yang telah dan akan dilakukan. Berdasarkan data yang diperoleh dari hasil penelitian untuk komponen ini sebesar 1.446, skor ini menunjukkan bahwa komponen ICT Use dikategorikan belum siap dalam pengembangan smart campus di IAIN Bukittiggi.

\section{Komponen ICT Readiness}

Komponen ICT Readiness terdiri dari dimensi sumber daya teknologi yang mencakup infrastruktur jaringan, hardware dan kanal akses, data informasi dan pengetahuan serta kompetensi sumber daya manusia. Berdasarkan hasil penelitian komponen ini memperoleh skor sebesar 2.807. angka ini menunjukkan bahwa komponen ini berada pada posisi hampir siap dan mendekati telah siap untuk pengembangan smart campus.

\section{Komponen ICT Capability}

Komponen ICT Capablity mencakup dimensi komunitas yang akan menjadi pengguna dari smart campus yang terdiri dari pimpinan, dosen, pengelola dan mahasiswa.berdasarkan data penelitian komponen ini memperoleh skor sebesar 1.914. Angka ini menunjukkan bahwa asumsi dari penggguna atas pentingnya smart campus masih sangat rendah hal ini bias disebabkan bahwa para calon pengguna belum atau tidak mengetahui atau belum merasakan impact dari penggunaan smart campus. Komponen ini berada pada posisi kurang siap dan mendekati hampir siap untuk pengembangan smart campus.

\section{Komponen ICT Impact}

Komponen ini terkait dengan "outcome" atau "value" yang dirasakan oleh komponen-komponen di PT dengan telah diimplementasinya ragam aplikasi ICT dalam smart campus. Komponen ini akan menjadi indikator akhir dari penerapan smart campus karena berasil atau tidaknya pengembangan smart campus akan terasa pa komponen ini. Berdasarkan data yang diperoleh dari penelitian, komponen ini memperoleh skor sebesar 2.900, angka ini menunjukkan bahwa pengembangan smart campus di IAIN Bukittinggi hampir berhasil dan mendekati telah berhasil.

Berdasarkan keempat komponen pengembangan model smart campus yang telah dibahas sebelumnya dapat diketahui bahwa secara keseluruhan kmponen IAIN Bukittinggi memperoleh skor sebesar 2.234, angka ini menunjukkan bahwa secara keseluruhan pengembangan model smart campus di IAIN Bukittinggi hamper berhasil dan memasuki tahap telah berhasil,

\section{KESIMPULAN DAN SARAN}

Berdasarkan analisis data di atas maka dapat diambil kesimpulan sebagai berikut :

Pengembangan cyber campus di IAIN Bukittinggi tidak dan belum menggunakan model pengembangan system.

Pengembangan cyber campus pada komponen ICT Use yang mencakup dimensi kebutuhan dan keselarasan serta dimensi proses dan tata kelola pada IAIN Bukittinggi baru memasuki pada tahap kurang siap. Sementara komponen ICT Readiness yang mencakup dimensi sumber daya teknologi sudah pada kategori hampir berhasil dan memasuki kategori telah berhsil. Komponen ICT Capability yang mencakup dimensi komunitas memasuki kategori belum berhasil akan tetapi sudah mendekati kategori hampir berhasil. Sementara pada komponen ICT impact sudah memasuki kategori hampir berhasil dan mendekati telah berhasil.

Secara keseluruhan komponen pengembangan cyber campus di IAIN Bukittinggi dikategorikan hampir berhasil.

Berdaarkan hasil penelitian ini dapat disarankan kepada perguruan tinggi terutama IAIN Bukittinggi untuk menjadikan informsi terkait indeks kesiapan implementasi TIK di kampus sebagai rujukan dan pertimbangan dalam rangka pengembangan TIK di masa yang akan datang.

\section{DAFTAR PUSTAKA}

BERTHO MOLLY, ANDEKA ROCKY TANAAMAH, M. N. N. S., 2017. Analisis Kerja Sistem Informasi dan Teknologi Informasi untuk Menunjang Kinerja Karyawan 
Menggunakan Framework IT Balanced Scorecard ( Studi Kasus Pada Wi-Fi Universitas Kristen Satya Wacana ). Jurnal Teknologi Informasi dan Ilmu Komputer (JTIIK), 4(4), 318-332. http://doi.org/10.25126/jtiik.201744499

CHOO, K.-K. R., 2011. The cyber threat landscape: Challenges and future research directions. Computers \& Security, 30(8), 719-731. http://doi.org/10.1016/j.cose.2011.08.004

HAN, I., \& HAN, S., 2014. Adoption of the Mobile Campus in a Cyber Mobile Campus Innovation in a Cyber University. The International Review of Research in Open and Distance Learning, 15(6), 237-256.

INDRAJIT, R. E., 2011. Profil dan Panduan Pelaksanaan Program ICT Pura. Kementrian Komunikasi dan Informatika Republik Indonesia (Kemkominfo), Dewan Teknologi Informasi dan Komunikasi Nasional (Detiknas), Federasi Teknologi Informasi Indonesia (FTII), dan Asosiasi Perguruan Tinggi dan Informatika Se-Indonesia (APTIKOM) (September), 1-107.

JUNG, I., \& RHA, I., 2000. A Virtual University Trial Project : Its Impact On Higher Education in South Korea. Innovations in Education \& Training International, 3297(November), 3141. http://doi.org/10.1080/1470329001002745

LEE, E., 2015. The Past, Present and Future of CyberPhysical Systems: A Focus on Models. Sensors, 15(3), $4837-4869$ http://doi.org/10.3390/s150304837

MUFTIKHALI, Q. E., \& SUSANTO, T. D., 2017. Kumpulan Model Maturity E-Government: Sebuah Ulasan, Jurnal Teknologi Informasi dan Ilmu Komputer (JTIIK) 4(4), 311-317. http://doi.org/10.25126/jtiik.201744367

SUPRATMAN., 2014. Islamic Cyber Campus (ICYCA) dan Pengukurannya Menggunakan Paradigma ICT Pura (Sebuah Model Pengembangan ICT di Pengajian Tinggi). (ACER-N Team 2014, Ed.) Prosiding Kolokium Antarabangsa Siswazah Pengajian Islam 2014. Kuala Lumpur Malaysia: Universiti Kebangsaan Malaysia.

WEITZEL, D., BOCKELMAN, B., FRASER, D., \& PORDES, R., 2011. Enabling Campus Grids with Open Science Grid Technology. International Conference on Computing in High Energy and Nuclear Physics. 062025. http://doi.org/10.1088/17426596/331/6/062025

LEE ABBOT, MARTIN AND MCKINNEY, JENNIFER., 2013. Understanding and Applying Research Design. Hoboken New Jersey: John Wiley and Sons, Inc.

SAEFUDDIN, AM, 2010. Islamisasi Sain dan Kampus. Jakarta: PT. PPA Consultants, Jakarta.
SUGIONO., 2013. Metode Penelitian Kombinasi (Mixing Methods). Bandung: Alfabeta. 
Halaman ini sengaja dikosongkan 